\title{
ピンオンディスク法による各種セラミックスの摩擦・摩耗特性
}

\author{
岩佐美喜男・樋 端 保 夫* \\ (大阪工業技術試験所 \\ * 現在：中国工業技術試験所)
}

代表的なファインセラミックスである $\mathrm{SiC}, \mathrm{Si}_{3} \mathrm{~N}_{4}, \mathrm{Al}_{2} \mathrm{O}_{3}$ 及び PSZ の各材質について, 原料, 助剤, 製法等の異なる幾つかの試料を選び，その相互間の摩擦・摩耗特性をピンオンディスク法に より測定した.

一定の相手ディスク材質に対する摺動に限定すれば, 摩擦係数, 比摩耗量は試料のビッカース硬 度に対しては負の相関を，破壊勒性に対しては正の相関を示すようであり，また摩擦係数と比摩耗 量の間には正の相関が認められた.

いずれの相手ディスクに対しても $\mathrm{SiC}$ ピンの摩擦係数, 比摩耗量が最も低く, 次いでいくらか ばらつきがあるものの $\mathrm{Al}_{2} \mathrm{O}_{3}$ ピンが優れている. $\mathrm{Si}_{3} \mathrm{~N}_{4}$ ピンは摩擦係数, 比摩耗量とも比較的高く, 摺動部材としての応用には摺動特性の改善の努力が必要であろう. PSZ ピンの摩擦係数, 比摩耗 量は相手ディスク材質によって大きく変動するが，相手ディスクの熱伝導率等に影響されていると 思われる.

ディスク材質としては, $\mathrm{SiC}, \mathrm{Si}_{3} \mathrm{~N}_{4}, \mathrm{Al}_{2} \mathrm{O}_{3}$ そして $\mathrm{PSZ}$ の順に相手ピンの摩耗が増大したが, ピン材質が $\mathrm{Al}_{2} \mathrm{O}_{3}$ の場合は逆の順序であった。

(1985 年 4 月 17 日受付)

\section{Friction and Wear of Ceramics Measured by a Pin-on-Disk Tester}

\author{
Mikio IWASA and Yasuo TOIBANA \\ $\left(\begin{array}{cl}\text { Government Industrial Research Institute, } & \text { Osaka } \\ \text { 8-31, Midorigaoka 1-chome, Ikeda-shi } & 563 \\ \text { * Now with Government Industrial Research Institute, Chugoku }\end{array}\right)$
}

\begin{abstract}
Friction and wear properties of ceramics were measured by a pin-on-disk tester. Four of the most promising fine-ceramics, $\mathrm{SiC}, \mathrm{Si}_{3} \mathrm{~N}_{4}, \mathrm{Al}_{2} \mathrm{O}_{3}$ and $\mathrm{PSZ}$ were selected, and several samples of each with different raw powders, additives or sintering processes were used in this experiment. The coefficient of friction and specific wear rate were correlated negatively with Vickers hardness, and positively with fracture toughness of pin samples for sliding on each disk material. Positive correlation was also observed between coefficient of friction and specific wear rate. $\mathrm{SiC}$ pins showed the lowest coefficient of friction and specific wear rate, followed by $\mathrm{Al}_{2} \mathrm{O}_{3}$ pins. As $\mathrm{Si}_{3} \mathrm{~N}_{4}$ pins showed a relatively higher coefficient of friction and specific wear rate, some improvement must be made for practical sliding part applications of $\mathrm{Si}_{3} \mathrm{~N}_{4}$ ceramics. The coefficient of friction and specific wear rate of PSZ pins changed drastically according to disk materials, perhaps as an effect of their thermal conductivity. Wear of atiy ceramic pins except $\mathrm{Al}_{2} \mathrm{O}_{3}$ pins was lowest for sliding on $\mathrm{SiC}$ disk, followed by $\mathrm{Si}_{3} \mathrm{~N}_{4}, \mathrm{Al}_{2} \mathrm{O}_{3}$ and then PSZ disk.

[Received April 17, 1985]
\end{abstract}

Key-words : Silicon carbide, Silicon nitride, Alumina, Partially stabilized zirconia, Friction and wear, Tribology, Pin-on-disk tester

\section{1. 緒 言}

炭化ケイ素や窒化ケイ素等の耐熱性に優れたファイン セラミックスはガスタービン, そのほかの高温構造材料 として期待されているが゙ ${ }^{1)}$ その実用化はもう少し遠い
将来のことであり，まずはセラミックスの室温付近での 高硬度, 耐摩耗性等を生かした摺動部材等への応用の可 能性が最も高いと思われる27.

そのような意味においても，七ラミックスの摩擦・摩 
耗の問題は非常に重要であり，最近ではかなり精力的に 研究が行われている31.4). しかしながら，現在までの報 告の多くは金属とセラミックス間の摺動や摺動相手セラ

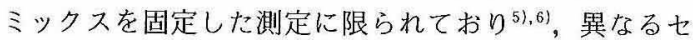
ラミックスの間の摺動に関する研究は少ないと言え る ${ }^{7), 8)}$. 七ラミックスの特性を生かした摺動部材として 使用するには，セラミックス一金属よりもセラミックスセラミックスの組み合わせの方が望ましいと考えられる が，同一材質間の䨪動では異常に高い摩耗を示す場合も あり，七ラミックス材質のいろんな組み合わせにおける 㩇動特性の検討はかなり重要であると思われるき，

ここでは非酸化物系の炭化ケイ素と窒化ケイ素，それ に酸化物系としてアルミナと最近注目されている相転移 強化部分安定化ジルコニアという 4 種の代表的なファイ ンセラミックスについて ${ }^{(0), 11)}$ ，原料，助剤，製法等の異 なる幾つかの試料を選び，その相互間の替動特性を測定 することにした。試験法としては単純な形状の試料を使 用でき，比較的高精度な摩擦係数，摩耗量の測定ができ
るピンオンディスク法を採用した ${ }^{12)}$.

\section{2. 実 験}

\section{1 試料}

本実験に用いた炭化ケイ素 $(\mathrm{SiC})$ ，窒化ケイ素 $\left(\mathrm{Si}_{3} \mathrm{~N}_{4}\right)$, アルミナ $\left(\mathrm{Al}_{2} \mathrm{O}_{3}\right)$ 及び部分安定化ジルコニ ア (PSZ) の試料破断面の走査型電子顕微鏡 (SEM) 写真の一部を図 1 に示した。

$\mathrm{SiC}$ につては，ホットプレス法 (HPSC)，常圧焼 結法 (NSSC)，それにSi 注入法 (RBSC) に上る 3 種 の狫結体を用いた列! X 線回折によるとHPSC と NSSC は完全な $\alpha$ 相, RBSC は $\alpha$ 相にいくらかの Si が残留していた。破断面の SEM 観察によれば，HPSC はほぼ完全にち密化していた.NSSC はHPSC に比べ て粒子が大きく，粒界に沿ってかなりの気孔が認められ た. RBSC は結合の弱いSi 部分で破壞するためか, 粒 界破壊に近い破断面を示し，粒子はいくらか丸みを抏び ている。
HPSC

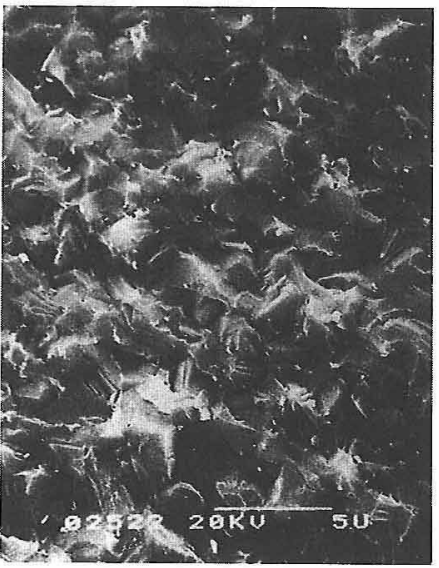

SSA-S

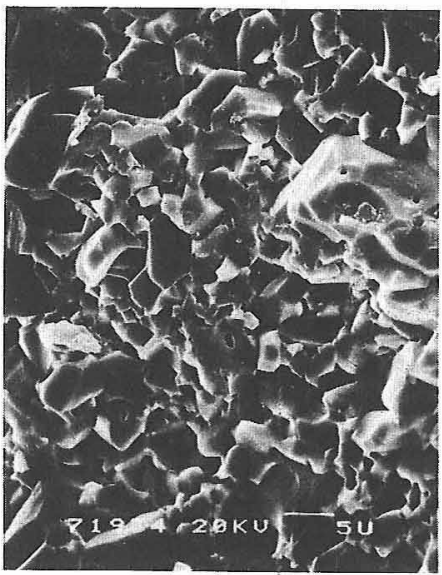

RBSC

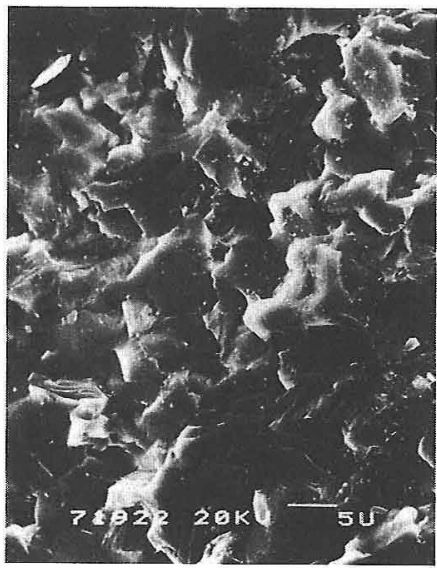

YTZ

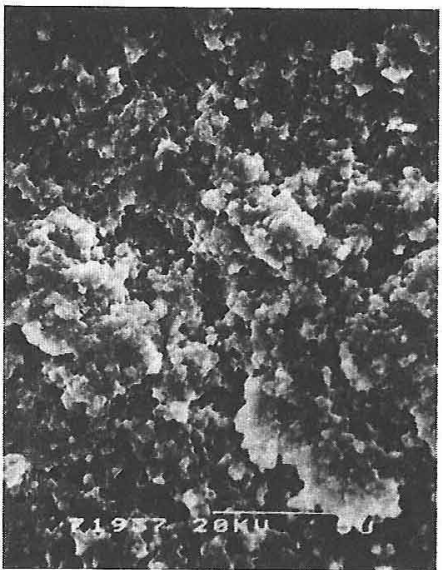

NSSN

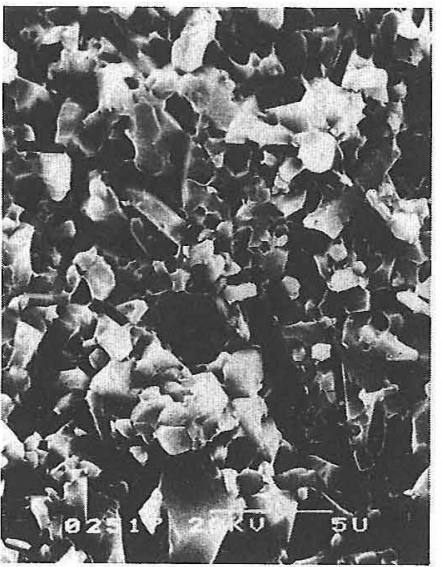

$Z R-8 Y$

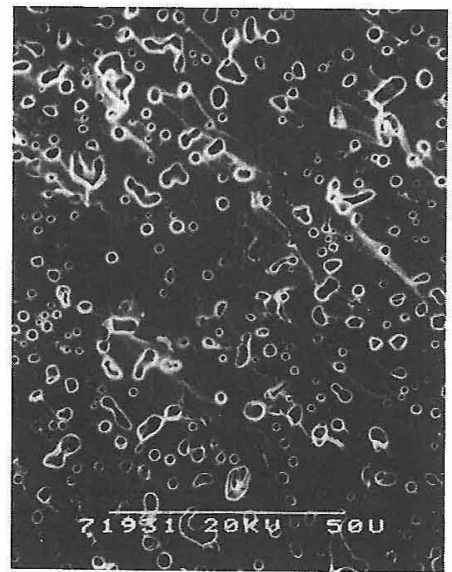

Fig. 1. Fracture surfaces of the ceramics used in this experiment. The bars are 5 or $50 \mu \mathrm{m}$. 
$\mathrm{Si}_{3} \mathrm{~N}_{4}$ については，ホットプレス品 (HPSN) と常圧 焼結品 (NSSN), 及び特に焼結助剤として $5 \mathrm{wt} \%$ $\mathrm{MgO}(5 \mathrm{MgO}), 5 \mathrm{~mol} \% \mathrm{Y}_{2} \mathrm{O}_{3}+5 \mathrm{~mol} \% \mathrm{Al}_{2} \mathrm{O}_{3}$ ( $5 \mathrm{Y} 5 \mathrm{~A}$ ), $5 \mathrm{~mol} \% \mathrm{Y}_{2} \mathrm{O}_{3}+5 \mathrm{~mol} \% \mathrm{La}_{2} \mathrm{O}_{3}$ (5 Y $5 \mathrm{~L}$ ) を $\mathrm{Si}_{3} \mathrm{~N}_{4}$ 粉末 (H. C. Starck 社, LC-10) に添加してホットプレス成

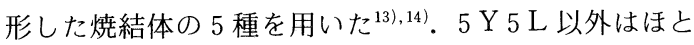
んご $100 \% \beta$ 化しており，すべて針状粒子がからみあっ た組織を有している. HPSN は粒径が小さく $1 \mu \mathrm{m}$ 程度, NSSN, $5 \mathrm{MgO}, 5 \mathrm{Y} 5 \mathrm{~A}$ は粒径 2 $5 \mu \mathrm{m}$ 程度であった。 5 Y 5 L は $\beta$ 化が不完全で約 $20 \%$ の $\alpha$ 相が残っており, 針状組織の発達も不十分であった。

$\mathrm{Al}_{2} \mathrm{O}_{3}$ については, 常圧焼成品 $\left(\mathrm{Al}_{2} \mathrm{O}_{3}-\mathrm{S}\right)$ 及び市販 の高純度アルミナ（日本化学陶業, SSA-S) を用いた. いずれもほとんど完全にち密化しているが, $\mathrm{Al}_{2} \mathrm{O}_{3}-\mathrm{S}$ の 方が粒子が細かく, 粒界の気孔が, また SSA-S では粒 内に取り残された気孔が若干認められた。

部分安定化ジルコニア (PSZ) としては, 市販の常 王焼結品 (日本化学陶業, YTZ) と HIP に上り高強度 化された焼結体 (PSZ-T) の 2 種, 及びそれらと比較 するために $\mathrm{Y}_{2} \mathrm{O}_{3}$ により完全に安定化された焼成品 (ZR-8 Y) を用いることにした. PSZ はいずれも 1 $\mu \mathrm{m}$ 以下の微粒子の集合体であり, 粒界破壊を示してい るが，ZR-8Y は大きく粒子成長しており，完全な粒内 破壊であり，粒内には多数の丸い気孔が認められる.

以上の各試料の機械的性質について若干調べた. ビッ カース硬度 $\left(H_{\mathrm{v}}\right)$ は荷重 $1 \sim 30 \mathrm{~kg}$ を 30 秒間印加して測 定した ${ }^{15)}$. 低荷重で幾分高い值を示す試料が幾つかあっ た以外は, ビッカース硬度の荷重依存性はほとんど認め られなかった。同時にビッカース圧痕の対角線方向に発 生するクラックの長さから Niihara らの式を用いて破壊 靶性 $\left(K_{\mathrm{Ic}}\right)$ を計算した ${ }^{16)}$. $K_{\mathrm{Ic}}$ については, 各試料より $3 \times 4 \times 40 \mathrm{~mm}$ の試験片を切り出し, ヌープ圧子で半円 形のクラックを導入後, 3 点曲げ強度試験を行う, いわ ゆる Controlled Surface Flaw Method でも測定し

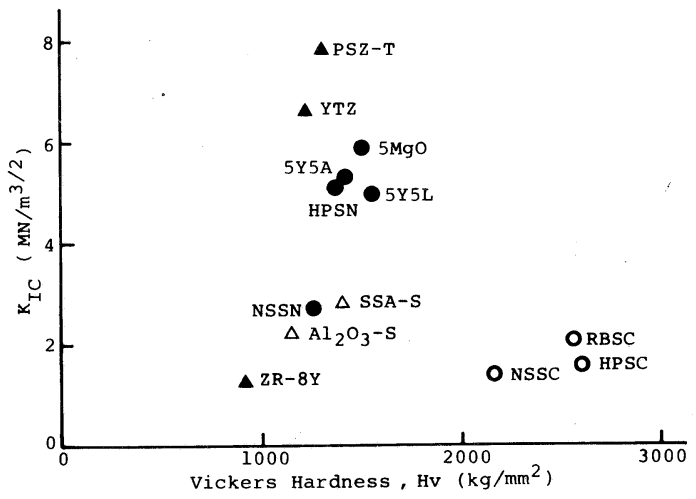

Fig. 2. The relation between Vickers hardness and fracture toughness of the samples.
$た^{17), 18)}$. 両測定値はかなり良好な相関を示したので ${ }^{19)}$, ここでは後者の值を使用することにした.

各試料のビッカース硬度と $K_{\mathrm{Ic}}$ の関係を図 2 に示し た. $\mathrm{SiC}$ は高硬度, 低鞀性, 逆に PSZ は高鞀性, 低硬 度であり，製法等による大きな差異は認められなかっ た.なお完全に安定化されているZR-8 Y の $K_{\mathrm{Ic}}$ は PSZ に比べて非常に低くなっている.ホットプレス法 の $\mathrm{Si}_{3} \mathrm{~N}_{4}$ では $K_{\mathrm{Ic}}$ が $5 \sim 6 \mathrm{MN} / \mathrm{m}^{3 / 2}$ であり，常圧焼結品 では $K_{\mathrm{IC}}, H_{\mathrm{v}}$ ともかなり低くなっている， $\mathrm{Al}_{2} \mathrm{O}_{3}$ は常圧 焼結の $\mathrm{Si}_{3} \mathrm{~N}_{4}$ と同じ程度の特性を有していると言える.

\section{2 ピンオンディスク法}

各セラミックス間の摩擦・摩耗特性はピンオンディス ク法により測定した. 試料ディスク $(60 \phi \times 10 \mathrm{~mm})$ の 中心から約 $25 \mathrm{~mm}$ の点に先端を半球状に加工した試料 ピン $(3 \times 4 \times 20 \mathrm{~mm})$ を荷重 $1 \mathrm{~kg}$ で押し付ける.モ一 ター, 変速機を通してディスクを一定速度で回転させる ことにより摺動実験を行う. ピンホルダーがロードセル を押し付ける機構により摩擦力が測定され, 摩耗量は試 料ピンの重量減少から求められる.ディスク側の摩耗量 も表面粗さ計等で摩耗痕の形状を測定すれば求められる が, 測定精度に問題があるので, ここではピン側の摩耗 量測定に限定することにした. 摩擦力, 摩耗量の摺動速 度依存性は本試験機の範囲ではほとんど認められなかっ たので ${ }^{12)}$, すべての摺動実験は回転数 $67 \mathrm{rpm}$, 摺動速 度 $18 \mathrm{~cm} / \mathrm{s}$ 程度の条件で行った。

図 3 に HPSN ディスク上で HPSC ピンを摺動させた 場合の測定例を示した。摩擦係数は摺動距離に対してほ とんど変化がなく, $\mu=0.2$ と求められる. 一方, ピン の重量減少は初期摩耗を除けば摺動距離に比例してい る.この直線の傾きから, 単位荷重, 単位摺動距離当た りの摩耗体積, すなわち比摩耗量が $W_{\mathrm{s}}=1.7 \times 10^{-9}$ $\mathrm{mm}^{3} / \mathrm{kg} \cdot \mathrm{mm}$ と計算される. 同様な方法でディスク側に HPSC, HPSN, $\mathrm{Al}_{2} \mathrm{O}_{3}-\mathrm{S}$ 及び $\mathrm{YTZ}$, ピン側にはすべ ての試料を用いて測定した. 試料ピンの摺動面はSEM で観察した。

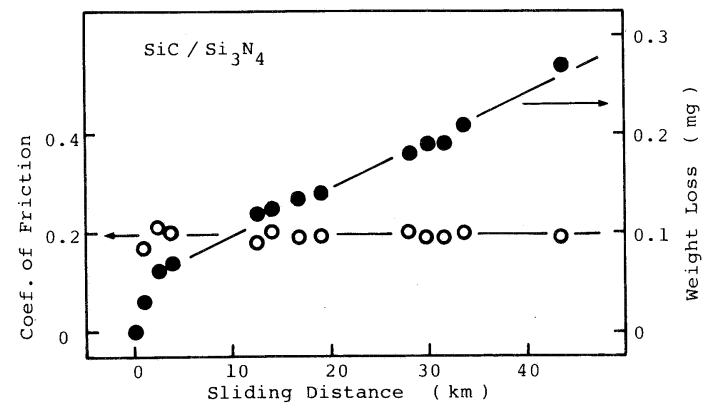

Fig. 3. Coefficient of friction and weight loss of HPSC pin sliding on HPSN disk, as a function of sliding distance. $P=1 \mathrm{~kg}, V=18 \mathrm{~cm} / \mathrm{s}$. 


\section{3. 結 果}

\section{1 炭化ケイ素に対する摺動}

ホットプレス炭化ケイ素 (HPSC) ディスクに対する 各試料ピンの摩擦係数, 比摩耗量をビッカース硬度を横 軸として図 4 に示した。摩擦係数については, SiC ピ ンが $\mu=0.2$ 程度, 他のセラミックスピンも $\mu=0.3$ 0.4 の範囲であり, SiC ディスクに対する摩擦係数はか なり低いと言える。比摩耗量については, SiC, PSZ ピンが $W_{\mathrm{s}}=10^{-9} \mathrm{~mm}^{2} / \mathrm{kg}$ 程度と非常に低く, $\mathrm{Al}_{2} \mathrm{O}_{3}$ ピ ンは $W_{\mathrm{s}}=10^{-8} \mathrm{~mm}^{2} / \mathrm{kg}$ 程度であり, いずれも同材質の 試料内の差異は比較的少ない。一方, $\mathrm{Si}_{3} \mathrm{~N}_{4}$ ピンは $W_{\mathrm{S}}$ $=10^{-7} \sim 10^{-8} \mathrm{~mm}^{2} / \mathrm{kg}$ の範囲にあり, 試料により 1 けた 近いばらつきが生じている. 同じデー夕を $K_{\mathrm{Ic}}$ に対して プロットしたのが図 5 である.摩擦係数, 比摩耗量亡ビッ カース硬度の関係はあまりはっきりしないが， $K_{\mathrm{Ic}}$ との 間にはいくらか正の相関が認められる.

\section{2 窒化ケイ素に対する摺動}

ホットプレス窒化ケイ素 (HPSN) ディスクに対する 摩擦係数, 比摩耗量を図 6 に示した. $\mathrm{SiC}$ ピンは $\mathrm{SiC}$ ディスクに対すると同様に摩擦係数, 比摩耗量ともかな り低い值を示していた. PSZ ピンの比摩耗量は SiC ディスクに対するよりも 1 けた近く上昇しており, $\mathrm{Si}_{3} \mathrm{~N}_{4}, \mathrm{Al}_{2} \mathrm{O}_{3}$ ピンも幾分か上昇している.なお, ZR-8 $\mathrm{Y}$ ピンは $\mathrm{SiC}$ ディスク以外では摺動により破損するこ
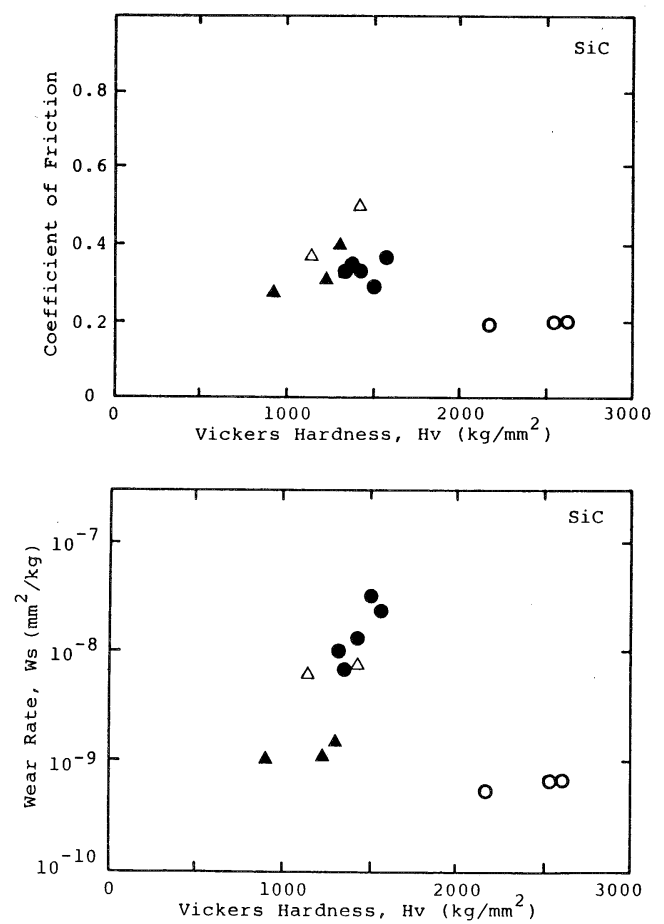

Fig. 4. Variations of coefficient of friction and specific wear rate of ceramic pins sliding on HPSC disk, in relation to their Vickers hardness. $\bigcirc: \mathrm{SiC}, \mathrm{:}: \mathrm{Si}_{3} \mathrm{~N}_{4}$, $\triangle: \mathrm{Al}_{2} \mathrm{O}_{3}, \boldsymbol{\Delta}: \mathrm{PSZ}$
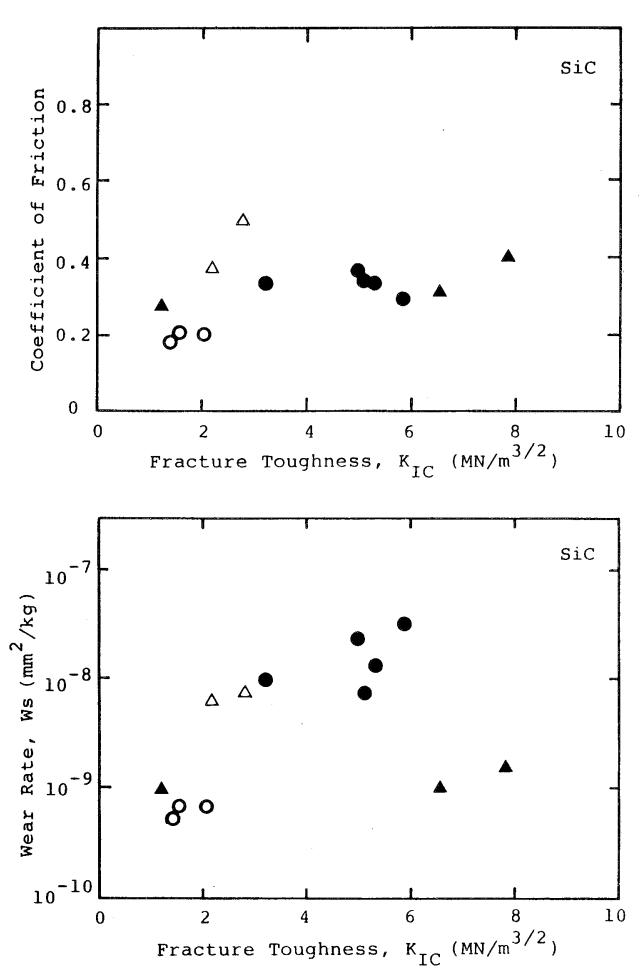

Fig. 5 Variations of coefficient of friction and specific wear rate of ceramic pins sliding on HPSC disk, in relation to their fracture toughness.
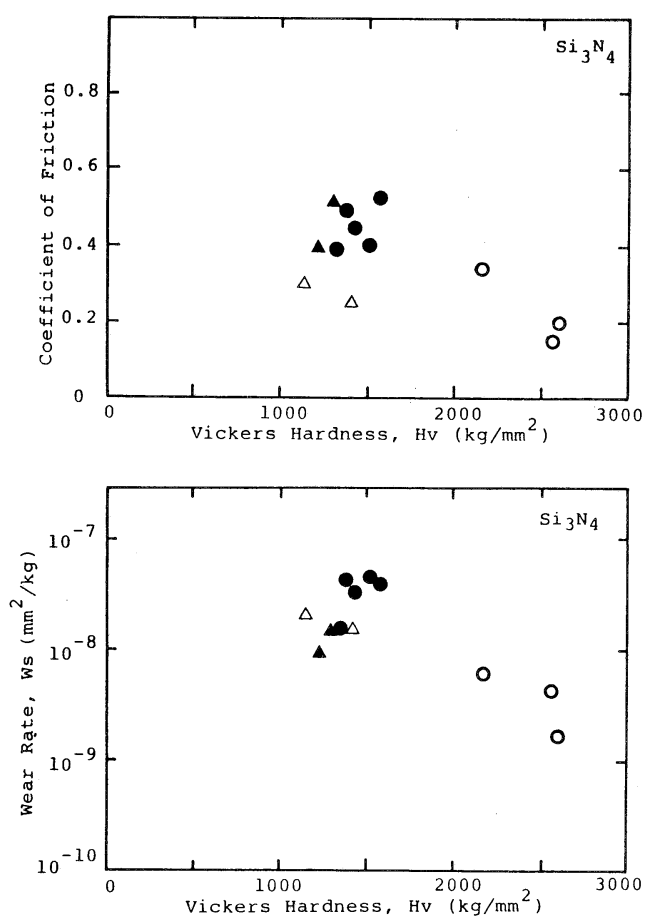

Fig. 6. Variations of coefficient of friction and specific wear rate of ceramic pins sliding on HPSN disk, in relation to their Vickers hardness. 
とが多く，測定は不可能であった．

摩擦係数, 比摩耗量とビッカース硬度の間には負の相 関があるようであり，一方， $K_{\mathrm{Ic}}$ との間には明らかに正 の相関が認められた. 図 7 に摩擦係数と比摩耗量の関係 を示したが，やはり正の相関が認められる。一般に摩擦 係数と比摩耗量の間には比例的な関係が成立するとされ ているが20), セラミックスについてもその関係があて はまと言える。

\section{3 常圧焼成アルミナに対する摺動}

常圧焼成アルミナ $\left(\mathrm{Al}_{2} \mathrm{O}_{3}-\mathrm{S}\right)$ ディスクに対する摺動 実験結果を図 8 に示した. $\mathrm{SiC}, \mathrm{Al}_{2} \mathrm{O}_{3}$ ピンの比摩耗量

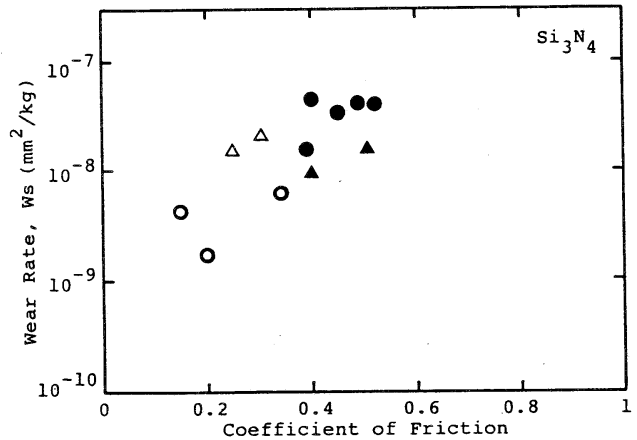

Fig. 7. The relation between coefficient of friction and specific wear rate of ceramic pins sliding on HPSN disk.
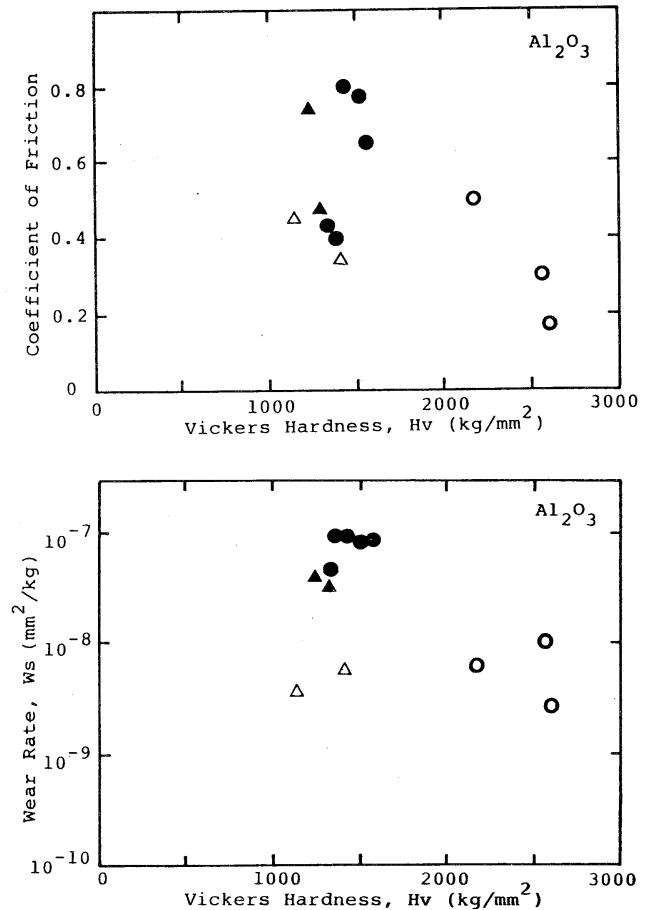

Fig. 8. Variations of coefficient of friction and specific wear rate of ceramic pins sliding on $\mathrm{Al}_{2} \mathrm{O}_{3}$ disk, in relation to their Vickers hardness.
は $W_{\mathrm{s}}=10^{-8} \mathrm{~mm}^{2} / \mathrm{kg}$ 以下であるが, $\mathrm{PSZ}$ ピンは $\mathrm{Si}_{3} \mathrm{~N}_{4}$ ディスクに対するよりも更に上昇している. $\mathrm{Si}_{3} \mathrm{~N}_{4}$ ピン の比摩耗量は $W_{\mathrm{s}}=10^{-7} \mathrm{~mm}^{2} / \mathrm{kg}$ 近くになり, $\mathrm{SiC}$, $\mathrm{Si}_{3} \mathrm{~N}_{4}$ ディスクに対するよりもかなり摩耗が激しいと言 える，摩擦係数についても $\mathrm{Si}_{3} \mathrm{~N}_{4}$ ディスクに対するより 全体的に高くなっている。摩擦係数, 比摩耗量とビッ カース硬度との間には負の相関が， $K_{\mathrm{Ic}}$ との間には正の 相関が幾分認められた。

\section{4 部分安定化ジルコニアに対する摺動}

常圧焼結の部分安定化ジルコニア (YTZ) ディスク に対する結果を図 9 に示した. $\mathrm{SiC}, \mathrm{Si}_{3} \mathrm{~N}_{4}, \mathrm{Al}_{2} \mathrm{O}_{3}$ ピン の比摩耗量は $\mathrm{Al}_{2} \mathrm{O}_{3}$ ディスクに対するのと同程度である が, PSZ ピンの比摩耗量は $W_{\mathrm{s}}=10^{-7} \mathrm{~mm}^{2} / \mathrm{kg}$ 以上と非 常に高くなっている. 摩擦係数, 比摩耗量とビッカース 硬度の間には負の相関があり, $K_{\mathrm{Ic}}$ とは正の相関が認め られた。

\section{4. 考察}

各セラミックス間の摩擦係数, 比摩耗量は, $\mathrm{Si}_{3} \mathrm{~N}_{4}$ ピ ンのように製法等による同材質の試料内のばらつきがか なり大きい場合もあるが，ほとんどはセラミックス材質 の組み合わせにより決定されていると言えるであろう. そこで, 各々のセラミックス材質の組み合わせに対して， 各試料について測定された摩擦係数, 比摩耗量の平均值
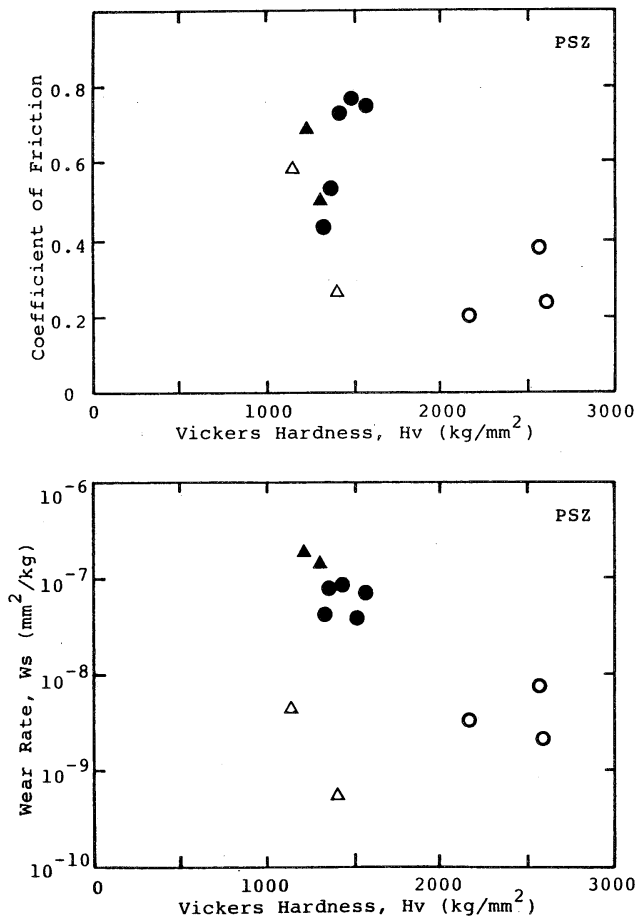

Fig. 9. Variations of coefficient of friction and specific wear rate of ceramic pins sliding on PSZ disk, in relation to their Vickers hardness. 
を用いてまよめると図 10 のようになる.

$\mathrm{SiC}$ ピンはいずれのディスクに対しても摩擦係数は $\mu$ $=0.2$, 比摩耗量は $W_{\mathrm{s}}=10^{-9} \mathrm{~mm}^{2} / \mathrm{kg}$ 程度之非常に低く, 優れた摺動特性を示していると言える．次いで若干のば らつきがあるものの, $\mathrm{Al}_{2} \mathrm{O}_{3}$ ピンが優れている. $\mathrm{Si}_{3} \mathrm{~N}_{4}$ ピンは摩擦係数が $\mu=0.4 \sim 0.8$, 比摩耗量が $W_{\mathrm{s}}=10^{-7}$ $\mathrm{mm}^{2} / \mathrm{kg}$ に近く，かなり高い值であり，摺動部材等とし て使用するには，もう少し摩擦係数，比摩耗量を下げる 工夫が必要であると思われる ${ }^{21)}$. PSZ ピンは少し特異 な挙動を示している．相手ディスク材質が $\mathrm{SiC}, \mathrm{Si}_{3} \mathrm{~N}_{4}$, $\mathrm{Al}_{2} \mathrm{O}_{3}, \mathrm{PSZ}$ の順に摩擦係数, 比摩耗量が増加していき, 特にPSZ ディスクに対しては $W_{\mathrm{s}}=10^{-7} \mathrm{~mm}^{2} / \mathrm{kg}$ 以上の 急速な摩耗を示している.この順位は試料ディスクの熱 伝導率の順位に一致しており，恐らく熱伝導が極端に悪 いPSZ ピンでは相手ディスクの熱伝導も悪ければ，摩 擦発熱により接触点がかなり高温になり，それが摩擦・ 摩耗に大きく影響しているのではないかと考えられる。

ディスク側のセラミックス材質としては, $\mathrm{Al}_{2} \mathrm{O}_{3}$ ピン に対しては逆転しているが, それ以外では $\mathrm{SiC}, \mathrm{Si}_{3} \mathrm{~N}_{4}$, $\mathrm{Al}_{2} \mathrm{O}_{3}, \mathrm{PSZ}$ の順に相手ピンの摩耗が増大していた。硬 度や熱伝導等の物理的性質や化学的性質が複雑に影響し ているのかもしれないが, 結論を得るにはもう少し詳し い実験が必要であると思われる.

摩耗の様子を検討するため, 各試料ピンの摺動面を
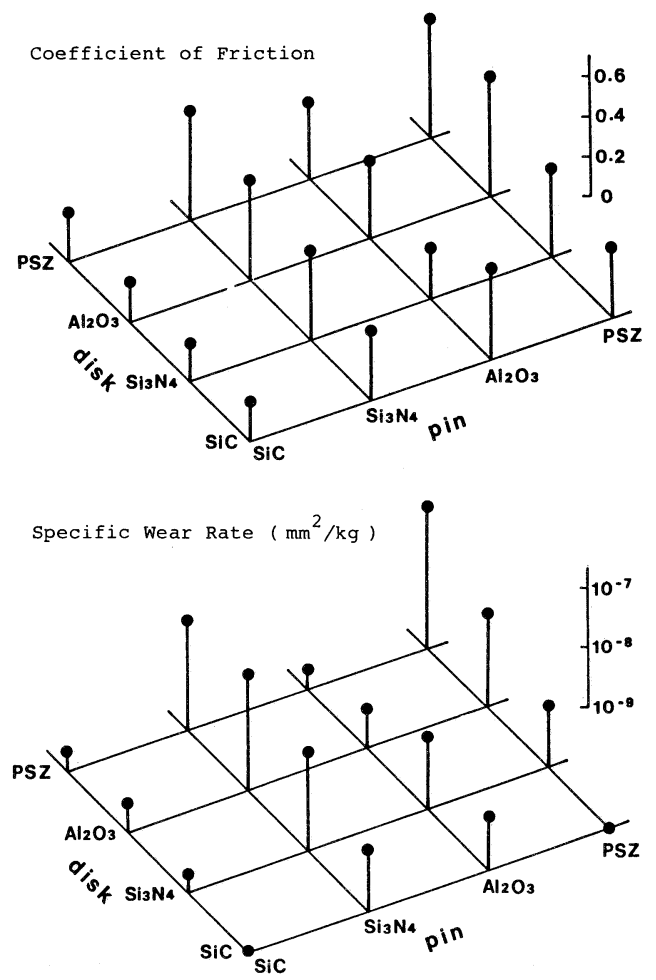

Fig. 10. Coefficient of friction and specific wear rate are plotted for each ceramic pin and disk combination.
SEM で調べた。 その SEM 写真の一部を図 11 に示し た. $\mathrm{SiC}$ ピンはいずれのディスクに対しても非常に平 たんな摺動面であり，摺動による粒子の脱落はほとんど 発生せず，各粒子がゆっくりとすり減っていくのみであ り，これが非常に低い摩擦係数, 比摩耗量と関係してい ると思われる. RBSC ピンでは粒界の $\mathrm{Si}$ 部分がエッチ ングされたように除去されている様子が観察されるが, $\mathrm{SiC}$ 粒子の摩耗は他の試料亡同様であろう. $\mathrm{Si}_{3} \mathrm{~N}_{4}$ ピン もかなり平たんな摺動面ではあるが，粒界にクラックが 発達し，構成粒子が少しずつ脱落していったと思われる 様子も認められ, $\mathrm{Si}_{3} \mathrm{~N}_{4}$ ピンのかなり高い比摩耗量が説 明されると思われる. $\mathrm{Al}_{2} \mathrm{O}_{3}$ ピンの摺動面には多くのク ラックや凹凸が認められ，アブレーシブな摩耗に特有な 条痕が観察される場合もあった。しかしながら， $\mathrm{Al}_{2} \mathrm{O}_{3}$ は $\mathrm{Si}_{3} \mathrm{~N}_{4}$ に比べると結晶粒子が大きいので，それだけ粒 子そのものの脱落が少なく，したがって $\mathrm{Si}_{3} \mathrm{~N}_{4}$ より比摩 耗量も低くなっているのではないかと考えられる. PSZ ピンでは摩擦係数や比摩耗量と同様に摺動面の様 子も相手ディスクによってかなり変化した。比摩耗量が 最も低い SiC ディスクに対しては非常に滑らかな摺動 面であった。相手ディスクが $\mathrm{Si}_{3} \mathrm{~N}_{4}, \mathrm{Al}_{2} \mathrm{O}_{3}$ へと比摩耗 量が増加していくとともに, 摺動面が破壊され結晶粒子 がいくらか取り去られていったと思われる様子も認めら れるようになってくる. 比摩耗量が最大となる PSZ ディスクに対しては摺動面の状態が大きく変わり, 多数 のクラックや変形の様子が観察される.

\section{5. 総 括}

代表的なファインセラミックスである $\mathrm{SiC}, \mathrm{Si}_{3} \mathrm{~N}_{4}$, $\mathrm{Al}_{2} \mathrm{O}_{3}$ 及び $\mathrm{PSZ}$ の各材質について, 原料, 助剂, 製法 等の異なる幾つかの試料を選び，その相互間の摩擦・摩 耗特性をピンオンディスク法により測定した.その結果, 以下の結論を得た。

（1）一定の相手ディスク材質に対する摺動に限定す れば, 摩擦係数, 比摩耗量は試料のビッカース硬度に対 しては負の相関を，破壊靶性に対しては正の相関を示す ようであり，また摩擦係数と比摩耗量の間には正の相関 が認められた。

(2) いずれの相手ディスクに対しても $\mathrm{SiC}$ ピンの 摩擦係数, 比摩耗量が最も低く, 次いでいくらかばらつ きがあるものの $\mathrm{Al}_{2} \mathrm{O}_{3}$ ピンが優れている. $\mathrm{Si}_{3} \mathrm{~N}_{4}$ ピンは 摩擦係数, 比摩耗量とも比較的高く, 摺動部材としての 応用には摺動特性の改善の努力が必要であろう。

(3) PSZ ピンの摩擦係数, 比摩耗量は相手ディス ク材質によって大きく変動するが，相手ディスクの熱伝 導率等に影響されていると思われる.

(4) ディスク材質としては, $\mathrm{SiC}, \mathrm{Si}_{3} \mathrm{~N}_{4}, \mathrm{Al}_{2} \mathrm{O}_{3}$ そ して PSZ の順に相手ピンの摩耗が増大したが，ピン材 

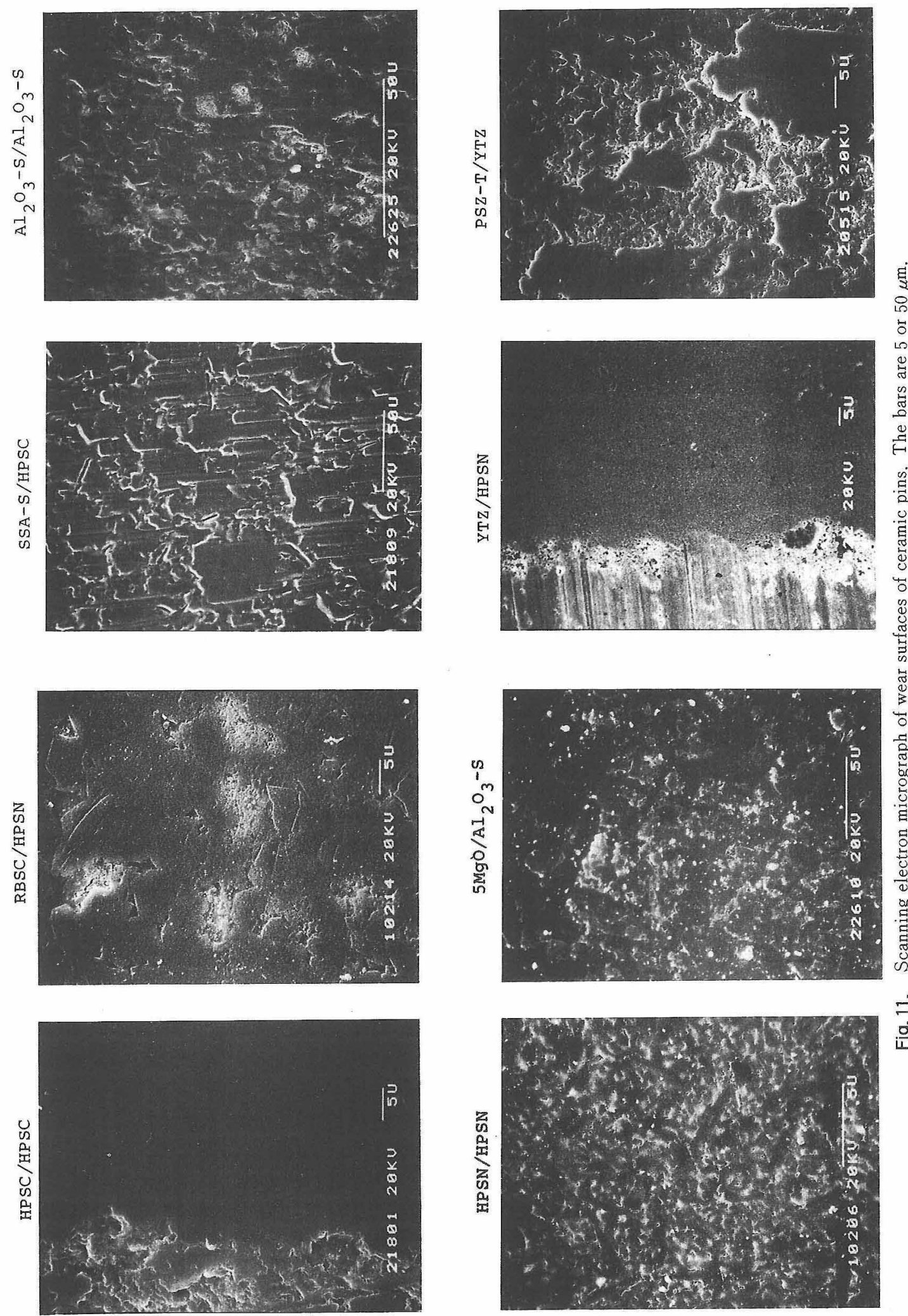
質が $\mathrm{Al}_{2} \mathrm{O}_{3}$ の場合は逆の順序であった。

\section{文献}

1) D.W. Richerson, Am. Ceram. Soc. Bull., 64, 282-86 (1985).

2）通商産業省生活産業局ファインセラミックス室, 工業技 術, 25, 20-28 (1984).

3）津谷裕子, “セラミックスの機械的性質”, 窯業協会編 (1979) p. 75-85.

4) D. H. Buckley and K. Miyoshi, Wear, 100, 333-53 (1984).

5) K. Miyoshi, D.H. Buckley and M. Srinivasan, Am. Ceram. Soc. Bull., 62, 494-500 (1983).

6) 佐藤準一, 山本治利, 望月善一, 川口直孝, 潤滑, 29, 775-78 (1984).

7) C.S. Yust and F. J. Carignan, Proc. of International Symposium on Ceramic Components for Engine, Japan (1983) p. 632-41.

8）高井重治, 岩永 寛, 住友金属, 36, 191-97 (1984).
9）岩佐美喜男, ファインセラミックス評価技術セミナー, 中部科学技術センター (1984) p. 125-41.

10）上垣外修己, 日本機械学会誌, 85, 1398-405 (1982).

11）五十嵐 昇, 工業材料, 33, 117-20 (1985).

12）岩佐美喜男, 樋端保夫, 吉村 茂, 小林英一, 窯協, 93, 73-80 (1985).

13) 米屋勝利, 工業材料, 31, 45-49 (1983).

14）上野和夫, 樋端保夫, 窯協, 91, 409-14 (1983).

15）松野外男, 若井史博, 阪口修司, “ファインセラミックス 評価技術集成”，リアライズ社（1984）p. 182-89.

16) K. Niihara, R. Morena and D.P.H. Hasselman, J. Mater. Sci. Letters, 1, 13-16 (1982).

17) J. J. Petrovic, L. A. Jacobson, P. K. Talty and A.K. Vasudevan, J. Am. Ceram. Soc., 58, 113-16 (1975).

18）岩佐美喜男, 上野 力, R.C. Bradt, 材料, 30, 100104 (1981).

19）岩佐美喜男, 溶射技術, 6, 1-10 (1985).

20）會田範宗, 潤滑, 20, 360-70 (1974).

21）岩佐美喜男, 垣内千一, 窯協, 93, 661-65 (1985). 